\title{
Peningkatan Service Level pada Sistem Antrian Pengambilan Obat di Puskesmas Bojong Rawalumbu Menggunakan Metode Simulasi
}

\author{
Increasing Service Level in Queuing System of Taking Medicine \\ at Public Health Center Bojong Rawalumbu Using Simulation Method
}

\author{
Mukhammad Azhari Isfirory, Agustian Suseno, Winarno \\ Program Studi Teknik Industri, Universitas Singaperbangsa Karawang \\ E-mail: mukhammad.azhari16096@student.unsika.ac.id, agustiansuseno@ staff.unsika.ac.id,
} winarno@staff.unsika.ac.id

\begin{abstract}
Abstrak
Antrian adalah keadaan di mana sekumpulan orang yang membutuhkan pelayanan harus menunggu dalam suatu urutan baris tertentu sebelum memperoleh pelayanan. Hal ini disebabkan oleh kemampuan memberikan pelayanan lebih kecil bila dibandingkan dengan kebutuhan akan suatu pelayanan. Permasalahan yang dihadapi oleh Puskesmas Bojong Rawalumbu adalah adanya antrian yang panjang pada loket pengambilan obat khususnya pada jam 08:00-09:00 WIB. Tujuan penelitian ini adalah untuk memperbaiki kinerja sistem antrian dan menentukan jumlah petugas loket pengambilan obat yang terbaik. Metode penyelesaian yang digunakan adalah metode simulasi sistem dan analisis workload indicator staffing needs. Berdasarkan hasil perhitungan menunjukkan bahwa kinerja awal sistem antrian pada Puskesmas Bojong Rawalumbu dengan jumlah petugas loket pengambilan obat sebanyak satu orang dengan waktu tunggu antrian selama 2,70 menit. Selanjutnya, berdasarkan usulan perbaikan kinerja sistem antrian, jumlah petugas loket sebanyak dua orang dan rata-rata waktu menunggu dalam antriannya turun menjadi 0,16 menit. Hal ini didukung dengan hasil analisis metode Workload Indicators Staffing Needs yang menunjukkan bahwa kebutuhan tenaga kerja untuk loket pengambilan obat sebanyak dua sampai tiga orang.
\end{abstract}

Kata kunci: Simulasi Antrian, Workload Indicators Staffing Needs, Optimasi Sistem Antrian

\begin{abstract}
Queuing is a condition in which a group of people who need service must wait in a certain sequence of lines before getting service. This is because the ability to provide services is smaller than the need for a service. The problem faced by Puskesmas Bojong Rawalumbu is the existence of long queues at the counter for drug collection, especially at 08: 00-09: 00 WIB. The purpose of this study was to improve the performance of the queuing system and determine the best number of counter officers for drug collection. The settlement method used is the system simulation method and workload indicator analysis of staffing needs. Based on the results of the calculation, it shows that the initial performance of the queuing system at the Bojong Rawalumbu Community Health Center is currently with the number of counter officers for drug collection as many as one person with a queue waiting time of 2.70 minutes. Furthermore, based on the proposed improvement in the performance of the queuing system, the number of counter attendants is two and the average waiting time in the queue has decreased to 0.16 minutes. This is supported by the results of the analysis of the Workload Indicators Staffing Needs method, which shows that there are two to three people needed for drug pick-up counters.
\end{abstract}

Keywords: Queuing Simulation, Workload Indicators Staffing Needs, Queue System Optimization. 


\section{Pendahuluan}

Antrian adalah orang atau benda yang menunggu untuk dilayani dalam urutan baris tertentu. Antrian dapat dijumpai pada fasilitas pelayanan umum di mana masyarakat atau barang akan mengalami proses antrian yang dimulai dari kedatangan, menunggu, hingga selesai dilayani (Heizer \& Render, 2015). Contoh kegiatan mengantri yang umum dalam kehidupan sehari-hari misalnya para pembeli yang mengantri di kasir sebuah supermarket, program yang menunggu untuk diproses oleh komputer digital, dan para pasien yang menunggu untuk mengambil obat di apotek.

Fenomena antrian dapat jumpai di sebuah Pusat Kesehatan Masyarakat. Pada Peraturan Menteri Kesehatan Republik Indonesia Nomor 75 Tahun 2014 Tentang Pusat Kesehatan Masyarakat Bab 1 Pasal 1 menyebutkan bahwa Pusat Kesehatan Masyarakat yang selanjutnya disebut Puskesmas adalah fasilitas pelayanan kesehatan yang menyelenggarakan upaya kesehatan masyarakat dan upaya kesehatan perseorangan tingkat pertama, dengan lebih mengutamakan upaya promotif dan preventif, untuk mencapai derajat kesehatan masyarakat yang setinggi-tingginya di wilayah kerjanya. Salah satunya adalah Puskesmas Bojong Rawalumbu yang beralamat di Perum Bumi Bekasi Baru Jalan Trisatya Raya jembatan 4-5, RT.001/RW.008, Bojong Rawalumbu, Kec. Rawalumbu, Kota Bekasi, Jawa Barat 17116. Puskesmas ini hadir untuk memenuhi pelayanan kesehatan masyarakat di Kota Bekasi khususnya wilayah Rawalumbu dan sekitarnya.

Antrian pada loket biasanya terjadi pada hari kerja yaitu hari Senin-Jum'at pada pukul 08:00-11:00 WIB. Panjang antrian selama pengamatan berkisar 4-7 pasien yang mengantri untuk mendapatkan obat. Permasalahan ini dapat dipecahkan dengan mencari elemen-elemen yang dibutuhkan dalam proses perhitungan sehingga nantinya dapat diperoleh suatu solusi yang sekurang-kurangnya dapat mengurangi panjang atau waktu antrian.

Model sistem antrian loket pengambilan obat di Puskesmas Bojong Rawalumbu adalah model single channel single phase. Penelitian ini dilakukan untuk menganalisis model sistem antrian di loket pengambilan obat sehingga dapat dijadikan masukan untuk pengambilan keputusan bagi pihak Puskesmas sehingga bisa memberikan kenyamanan pelayanan bagi pasien namun juga tidak merugikan bagi pihak Puskesmas. Pada penelitian ini menggunakan simulasi secara manual dan menggunakan software ProModel. Simulasi secara manual dilakukan dengan menyusun tabel simulasi yang memuat perhitungan-perhitungan karena adanya kejadian yang muncul dari awal sampai akhir simulasi. Setelah simulasi selesai dilakukan, kebutuhan jumlah pekerja dianalisis menggunakan metode Workload Indicator Staffing Needs (WISN).

\section{Tinjauan Pustaka}

\subsection{Sistem Antrian}

Teori antrian atau queue theory merupakan alat dan juga bagian penting dalam manajemen operasi. Teori ini dikemukakan oleh A. K. Erlang. Model antrian sangat berguna dalam bidang manufaktur maupun jasa. Antrian terjadi karena adanya satu orang atau lebih yang sedang menunggu suatu pelayanan (Krajewski, Ritzman, \& Malhotra, 2010), namun demikian antrian dapat juga dialami oleh suatu barang atau benda kerja yang menunggu proses selanjutnya (Heizer \& Render, 2015). Sedangkan teori antrian mengkaji antrian tersebut dengan melakukan studi matematis (Dimyati \& Dimyati, 2011). Berdasarkan pernyataan-pernyataan tersebut, dapat disimpulkan bahwa sistem antrian merupakan kumpulan orang atau barang yang berbaris untuk menunggu pelayanan dan meninggalkan sistem ketika selesai.

\subsection{Simulasi Sistem}

\subsubsection{Konsep Dasar}

Kelton, Sadowski, and Zupick (2015) mengemukakan bahwa simulasi adalah metode atau aplikasi untuk meniru kebiasaan sistem yang sesuai kenyataan, umumnya dengan sistem komputer yang sesuai. Sedangkan menurut Setyaningsih and Basri (2013) model simulasi adalah penggambaran model matematis dari masalah yang ada. Dengan melakukan simulasi, akan dapat memberikan alternatif-alternatif dan juga solusi untuk pemecahan masalah yang sedang diteliti. Model simulasi menggambarkan hubungan antara input dan output dari sebuah sistem yang kompleks. Hal yang 
terpenting dalam melakukan simulasi adalah melakukan pemetaan terhadap masalah yang kompleks.

Menurut Heizer and Render (2015) simulasi adalah tindakan untuk meniru fitur, penampilan, dan karakteristik sistem yang nyata. Simulasi memiliki tiga bagian, yaitu 1) meniru situasi dalam dunia nyata secara matematika, 2) mempelajari propertinya dan karakteristik operasional, dan 3) menarik kesimpulan dan mengambil keputusan tindakan berdasarkan pada hasil simulasi. Dengan jalan ini, sistem dunia nyata tidak disentuh hingga kelebihan dan kekurangan kebijakan keputusan utama yang diukur pertama dalam model. Untuk menggunakan simulasi harus melakukan beberapa hal meliputi: 1) mendefinisikan permasalahan, 2) memperkenalkan variabel yang penting yang terkait dengan permasalahan, 3) membangun model numerik, 4) menetapkan kemungkinan serangkaian tindakan untuk pengujian dengan menentukan nilai variabel, 5) menjalankan percobaan, 6) mempertimbangkan hasilnya, dan 7) memutuskan apa serangkaian tindakan yang akan diambil.

Permasalahan yang dapat diatasi dengan simulasi berkisar dari yang sangat sederhana hingga terlalu kompleks. Meskipun simulasi yang sangat kompleks dapat dikerjakan dengan tangan, tetapi penggunaan teknik yang efektif memerlukan komputer. Model skala besar, menyimulasi mungkin bertahun-tahun keputusan dalam bisnis semuanya benar-benar ditangani dengan komputer.

\subsubsection{Discrete-Event Simulation (DES)}

Discrete-Event Simulation adalah simulasi yang membahas model suatu sistem yang selalu berkembang karena adanya representasi perubahan variabel-variabel pada kondisi tertentu di saat tertentu. Dijelaskan juga bahwa DES secara konsep dapat dikerjakan dengan menggunakan perhitungan-perhitungan secara manual, tetapi oleh karena begitu banyak data yang akan diproses di mana dibutuhkan media penyimpanan atas proses-proses tersebut maka penyelesaian permasalahan menggunakan DES disarankan untuk menggunakan media komputer. Pada penelitian ini, pendekatan yang digunakan adalah discrete event karena discrete event merupakan pendekatan simulasi untuk sistem yang memiliki tahapan proses waktu tertentu.

\subsubsection{ProModel}

ProModel atau Production Modeler merupakan software yang berfungsi mensimulasikan atau memodelkan baik sistem manufaktur maupun pelayanan. Sistem manufaktur seperti flow lines, job shop, conveyors, perakitan, sistem Just-in Time, bisa dimodelkan menggunakan ProModel. Sebelum melakukan simulasi dengan ProModel data yang dibutuhkan ada dua yaitu data waktu kedatangan dan data waktu pelayanan. ProModel yang digunakan adalah ProModel student version 7.5.

\subsection{Workload Indicators of Staffing Need (WISN)}

WISN adalah metode perhitungan kebutuhan sumber daya manusia (SDM) untuk penyusunan perencanaan sumber daya manusia kesehatan di tingkat propinsi, kabupaten/kota serta rumah sakit (Kesehatan, 2004). Metode WISN adalah alat manajemen SDM untuk menentukan kebutuhan tenaga kesehatan dan dapat mengatasi beban kerja yang diberikan (Organization, 2010).

WISN berfungsi untuk penentuan jumlah petugas pengambilan obat (server), sehingga hasil dari pemilihan solusi jumlah server pada simulasi tetap sesuai dengan standar ketentuan jumlah tenaga kerja untuk bagian kesehatan. Metode WISN memiliki lima langkah perhitungan yaitu penetapan waktu tersedia, penentuan unit kerja tersedia, dan kategori SDM, pembobotan standar beban kerja, penetapan standar kelonggaran, dan perhitungan kebutuhan SDM per unit kerja.

1. Menetapkan waktu kerja tersedia

Penentuan waktu kerja tersedia berfungsi untuk mengetahui waktu kerja yang tersedia di setiap kategori SDM dalam satu tahun. Data yang dibutuhkan meliputi:

a. Jumlah hari kerja yang tersedia (A)

b. Total cuti tahunan (B)

c. Lama waktu pendidikan dan pelatihan sesuai ketentuan yang berlaku di instansi terkait (C)

d. Hari libur nasional (D)

e. Rata-rata ketidak hadiran kerja selama satu tahun (E) 
f. Jam kerja berdasarkan peraturan yang berlaku (F)

Berdasarkan data tersebut diketahui untuk menentukan waktu kerja tersedia dengan formula (1). Dalam formula tersebut, $A$ menyatakan hari kerja, $B$ merupakan cuti tahunan, $C$ adalah pendidikan dan pelatihan, $D$ merupakan hari libur nasional, $E$ menunjukkan ketidakhadiran kerja, dan $F$ adalah waktu kerja.

Waktu Kerja Tersedia $=\{A-(B+C+D+E)\} \times F$

2. Menetapkan Unit kerja dan Kategori SDM

Penetapan unit kerja dan kategori SDM bertujuan untuk memperoleh unit kerja dan kategori SDM yang bertanggung jawab atas berlangsungnya kegiatan pelayanan kesehatan. Data yang diperlukan adalah:

a. Bagan struktur organisasi instansi terkait dengan uraian tugas dan fungsinya

b. Keputusan direktur instansi terkait tentang pembentukan unit kerja struktural dan fungsional

c. Data pegawai yang bekerja pada tiap unit kerja di instansi terkait

d. PP nomor 32 tahun 1996 tentang SDM kesehatan

e. Peraturan perundangan tentang jabatan fungsional SDM kesehatan

f. Standar profesi, standar pelayanan dan standar operasional prosedur (SOP) pada tiap unit kerja instansi terkait

3. Menyusun Standar Beban Kerja (SBK)

Standar beban kerja merupakan jumlah beban kerja selama satu tahun setiap kategori SDM. SBK mengacu pada waktu yang dibutuhkan untuk menyelesaikan rata-rata waktu dan waktu yang tersedia per tahun yang dimiliki oleh setiap kategori tenaga. Rumus untuk perhitungan standar beban kerja menggunakan rumus (2).

$$
\text { Standar Beban Kerja }=\frac{\text { Rata }- \text { rata waktu kerja tersedia }}{\text { rata }- \text { rata waktu peraturan kegiatan pokok }}
$$

4. Menyusun Standar Kelonggaran

Penyusunan standar kelonggaran bertujuan untuk diperolehnya faktor kelonggaran pada tiap kategori SDM. Penyusunan faktor kelonggaran dapat dilakukan wawancara dan pengamatan langsung untuk mendapatkan datanya:

a. Kegiatan tidak langsung dengan pelayanan ke pasien.

b. Frekuensi kegiatan dalam satuan waktu.

c. Lama penyelesaian kegiatan.

Berdasrkan faktor kelonggaran di atas selanjutnya adalah menentukan standar kelonggaran dengan rumus (3).

$$
\text { Standar Kelonggaran }=\frac{\text { Rata }- \text { rata waktu perfaktor kelonggaran }}{\text { Waktu kerja tersedia }}
$$

5. Perhitungan Kebutuhan SDM

Perhitungan ini bertujuan untuk diperolehnya jumlah SDM yang mampu bekerja dengan beban kerja dalam satu tahun. Informasi yang diperlukan untuk menentukan jumlah SDM per unit kerja meliputi:

a. Data dari langkah sebelumnya, yaitu ketersediaan waktu kerja, SBK dan standar kelonggaran tiap-tiap di kategori

b. Jumlah kegiatan utama tiap unit kerja dalam waktu satu tahuan. Kegiatan pokok harus disusun berdasarkan berbagai data kegiatan pelayanan yang telah dilaksanakan di tiap unit kerja pada instansi terkait selama kurun waktu satu tahun

Kebutuhan jumlah SDM disetiap unit kerja dihitung menggunakan rumus (4).

Kebutuhan SDM $=\frac{\text { Kuantitas kegiatan pokok }}{\text { Standar beban kerja }}+$ Standar Kelonggaran

Berdasarkan rumus perhitungan tersebut, kebutuhan SDM untuk tiap kegiatan pokok terlebih dahulu di jumlahkan sebelum ditambahkan dengan standar kelonggaran masing-masing kategori SDM.

Menurut Shipp and Organization (1998) bagian akhir dari perhitungan WISN yang berhubungan dengan pengambilan keputusan yaitu rasio. Rasio antara kenyataan dan kebutuhan, inilah yang dimaksud dengan ketentuan WISN: 
1. Rasio WISN = 1 berarti jumlah SDM sesuai dengan beban kerja berdasar SOP yang telah ditetapkan

2. Rasio WISN < 1 berarti jumlah SDM yang ada belum sesuai dengan beban kerja

3. Rasio WISN $>1$ berarti SDM berlebihan

\subsection{Penelitian Terdahulu}

Penelitian terkait dengan metode simulasi telah dilakukan di berbagai bidang. Bidang-bidang tersebut antara lain pusat pelayanan kesehatan seperti rumah sakit dan apotek, kantor pemerintahan untuk pelayanan masyarakat, penjadwalan kendaraan, sekolah, operasional bongkar muat barang di pelabuhan, proses produksi, dan stasiun pengisian bahan bakar.

Penelitian bidang pelayanan kesehatan telah dilakukan pada proses pelayanan resep non racikan di Instalasi Farmasi Rawat Jalan RS Islam Jemursari Depo 1 (Sujoko \& Chalidyanto, 2015). Hasil penelitian tersebut dapat meningkatkan tingkat pelayanan dan tingkat utilitas masing-masing $81 \%$ dan 73\%. Penelitian serupa dilakukan oleh Utami and Rumita (2016) di RSUD Dr. Soeselo Slawi dengan model multiple channel single phase dan mengusulkan penambahan jumlah pegawai sebanyak 9 (sembilan) orang agar memenuhi waktu pelayanan yang ditetapkan. Penelitian lainnya disampaikan oleh Nasution and Mutia (2017), dengan mengusulkan tambahan satu loket untuk mengurangi waktu antrian pada pelayanan pendaftaran Puskesmas Padang Pasir. Metode simulasi juga diterapkan pada sistem antrian poli jantung RSUD Kota Langsa oleh Amalia, Saumi, Novianti, and Ulfa (2018), dimana jumlah terbanyak pasien yang menunggu sebanyak 14 orang dengan ratarata waktu tunggu selama 56,28 menit. Sedangkan hasil penelitian Falen and Subagyo (2018) menunjukkan bahwa adanya penambahan 10 ruangan VIP dapat mengurangi waktu tunggu pasien yang akan dirawat pada kelas VIP. Penelitian tersebut dilengkapi dengan analisis ekonomi teknik untuk mendukung penambahan ruang VIP tersebut. Penelitian lain bidang pelayanan kesehatan ditunjukkan oleh Mulyati, Qasir, Alsyah, Yana, and Satria (2019), dimana penambahan fasilitas pelayanan dapat mengurangi waktu tunggu pembeli obat di Apotek Ingin Jaya Aceh Besar. Analisis sistem antrian pada Puskesmas Cebongan, Salatiga menunjukkan bahwa pada bagian cek tekanan darah dan pengambilan obat waktu tunggunya masih besar (Muninggar, Linawati, \& Parhusip, 2019).

Selanjutnya, penelitian terkait metode simulasi pada kantor pemerintahan untuk pelayanan masyarakat telah dilakukan oleh Mukarrama and Fadjryani (2017), menunjukkan bahwa penambahan satu loket pendaftaran dapat mengurangi waktu tunggu wajib pajak yang akan membayar pajak pada kantor Samsat Kota Palu. Sedangkan adanya pelayanan yang lambat terungkap pada proses pembuatan e-KTP Kelurahan Kebon Pala Makassar, dimana utilitas pelayanan masih 50\% (Cornellia, 2018). Demikian juga penelitian yang dilakukan oleh Mahessya, Putra, and Veri (2019) menunjukkan bahwa sistem antrian pembuatan SIM di Polres menggunakan metode monte carlo dengan Multi Channel Multi Phase lebih efektif dibandingkan dengan kondisi nyatanya.

Penelitian-penelitian lainnya terkait metode simulasi antara lain dilakukan pada penjadwalan keberangkatan angkutan umum di setiap halte yang dilaluinya, menunjukkan bahwa pemilihan waktu interval sangat berpengaruh terhadap pendapatn harian supir (Winarno, 2014), bongkar muat kapal tanker di pelabuhan yang memiliki tingkat utilitas berkisar $90 \%$ sehingga perlu ada perbaikan (Camerling \& Manusiwa, 2017), pelayanan akademik di sekolah menengah kejuruan (Jatmika, Prasetyo, \& Poernomo, 2017), proses produksi perusahaan manufaktur (Trenggonowati, 2017), dan stasiun pengisi bahan bakar umum yang perlu diatur ulang penjadwalan pegawainya (Kusumaningtyas, Fikri, \& Liquiddanu, 2018).

Perbedaan penelitian yang ini dengan penelitian terdahulu yang telah dipaparkan di atas adalah penelitian ini dilakukan di salah satu pelayanan kesehatan, yaitu Puskesmas. Sistem antrian yang diamati dalam penelitian ini adalah antrian pada loket pengambilan obat. Model sistem antrian loket pengambilan obat adalah model single channel single phase. Penelitian ini dilakukan untuk menganalisis model sistem antrian di loket pengambilan obat sehingga dapat dijadikan masukan 
untuk pengambilan keputusan bagi pihak Puskesmas sehingga bisa memberikan kenyamanan pelayanan bagi pasien namun juga tidak merugikan bagi pihak Puskesmas. Pada penelitian menggunakan simulasi dengan bantuan software ProModel dan dianalisis juga kebutuhan pekerja yang ideal dengan metode WISN. Sehingga solusi akhir yang dipilih nanti akan sesuai dengan hasil simulasi yang terbaik dan tetap sesuai dengan standar yang ditetapkan pemerintah berdasarkan metode WISN.

\section{Pembahasan}

\subsection{Proses Pengambilan Obat pada Puskesmas Bojong Rawalumbu}

Proses pengambilan obat pada Puskesmas Bojong Rawalumbu digambarkan secara jelasnya gambar 1.

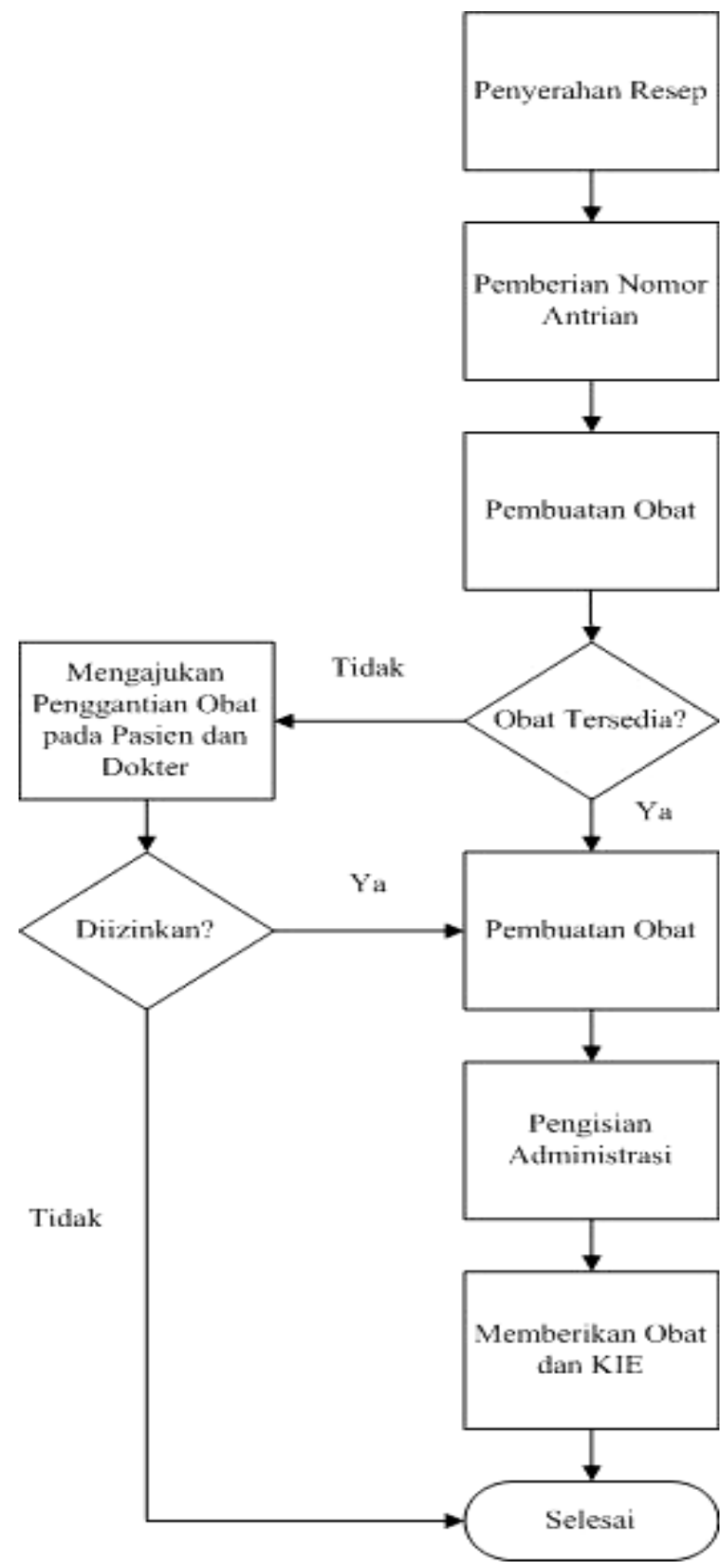

Gambar 1. Urutan Proses Pengambilan Obat 


\subsection{Pengumpulan Data}

Berikut adalah data kedatangan dan data waktu pelayanan pasien yang didapatkan dari hasil pengamatan pada hari kerja di tanggal 5-18 Maret 2020 pada waktu padat yaitu jam 08.00-11.00 WIB.

\subsubsection{Data Kedatangan Pelanggan}

Data kedatangan pasien diambil secara langsung di Puskesmas Bojong Rawalumbu yang ditunjukkan pada tabel 1 .

Tabel 1. Data Kedatangan Pasien

\begin{tabular}{|c|c|c|c|}
\hline No & Hari/Tanggal & $\begin{array}{l}\text { Periode Waktu } \\
\text { (Per Jam) }\end{array}$ & $\begin{array}{c}\text { Kedatangan } \\
\text { (Pasien) }\end{array}$ \\
\hline \multirow{3}{*}{1} & \multirow{3}{*}{$\begin{array}{c}\text { Kamis } 5 \\
\text { Maret } 2020\end{array}$} & 08:00-09:00 & 29 \\
\hline & & 09:00-10:00 & 42 \\
\hline & & 10:00-11:00 & 28 \\
\hline \multirow{3}{*}{2} & \multirow{3}{*}{$\begin{array}{c}\text { Jum'at } 6 \\
\text { Maret } 2020\end{array}$} & 08:00-09:00 & 40 \\
\hline & & 09:00-10:00 & 33 \\
\hline & & 10:00-11:00 & 51 \\
\hline \multirow{3}{*}{3} & \multirow{3}{*}{$\begin{array}{c}\text { Senin } 9 \text { Maret } \\
2020\end{array}$} & 08:00-09:00 & 29 \\
\hline & & 09:00-10:00 & 32 \\
\hline & & 10:00-11:00 & 33 \\
\hline \multirow{3}{*}{4} & \multirow{3}{*}{$\begin{array}{l}\text { Selasa } 10 \\
\text { Maret } 2020\end{array}$} & 08:00-09:00 & 35 \\
\hline & & 09:00-10:00 & 41 \\
\hline & & 10:00-11:00 & 32 \\
\hline \multirow{3}{*}{5} & \multirow{3}{*}{$\begin{array}{c}\text { Rabu } 11 \\
\text { Maret } 2020\end{array}$} & 08:00-09:00 & 35 \\
\hline & & 09:00-10:00 & 31 \\
\hline & & 10:00-11:00 & 33 \\
\hline \multirow{3}{*}{6} & \multirow{3}{*}{$\begin{array}{c}\text { Kamis } 12 \\
\text { Maret } 2020\end{array}$} & 08:00-09:00 & 23 \\
\hline & & 09:00-10:00 & 31 \\
\hline & & 10:00-11:00 & 38 \\
\hline \multirow{3}{*}{7} & \multirow{3}{*}{$\begin{array}{l}\text { Jum'at } 13 \\
\text { Maret } 2020\end{array}$} & 08:00-09:00 & 33 \\
\hline & & 09:00-10:00 & 38 \\
\hline & & 10:00-11:00 & 19 \\
\hline \multirow{3}{*}{8} & \multirow{3}{*}{$\begin{array}{c}\text { Senin } 16 \\
\text { Maret } 2020\end{array}$} & 08:00-09:00 & 41 \\
\hline & & 09:00-10:00 & 39 \\
\hline & & 10:00-11:00 & 45 \\
\hline \multirow{3}{*}{9} & \multirow{3}{*}{$\begin{array}{c}\text { Selasa } 17 \\
\text { Maret } 2020\end{array}$} & 08:00-09:00 & 34 \\
\hline & & 09:00-10:00 & 23 \\
\hline & & 10:00-11:00 & 30 \\
\hline \multirow{3}{*}{10} & \multirow{3}{*}{$\begin{array}{c}\text { Rabu } 18 \\
\text { Maret } 2020\end{array}$} & 08:00-09:00 & 27 \\
\hline & & 09:00-10:00 & 27 \\
\hline & & 10:00-11:00 & 38 \\
\hline & & & 1010 \\
\hline
\end{tabular}

$\lambda=\frac{\text { jumlah kedatangan pasien }}{\text { jumlah selang waktu antar kedatangan pasien }}$

$\lambda=\frac{1010}{28,17}=35,86 \approx 36$ pasien $/ \mathrm{jam}$

Berdasarkan data kedatangan pasien dapat diketahui tingkat kedatangan $(\lambda)$ yang dimiliki adalah 37 orang atau 1,67 menit/orang. 
PENINGKATAN SERVICE LEVEL (Mukhammad A. I., dkk.)

\subsubsection{Data Waktu Pelayanan Pasien}

Data Waktu Pelayanan pasien diambil secara langsung di Puskesmas Bojong Rawalumbu yang ditunjukkan pada tabel 2.

Tabel 2. Data Lama Waktu Pelayanan Pasien

\begin{tabular}{|c|c|c|c|}
\hline No & Hari/Tanggal & $\begin{array}{l}\text { Periode Waktu } \\
\text { (Per Jam) }\end{array}$ & $\begin{array}{l}\text { Lama Pelayanan } \\
\text { (menit) }\end{array}$ \\
\hline \multirow{3}{*}{1} & \multirow{3}{*}{$\begin{array}{l}\text { Kamis } 5 \\
\text { Maret } 2020\end{array}$} & 08:00-09:00 & 24,33 \\
\hline & & 09:00-10:00 & 51,13 \\
\hline & & 10:00-11:00 & 32,53 \\
\hline \multirow{3}{*}{2} & \multirow{3}{*}{$\begin{array}{c}\text { Jum'at } 6 \\
\text { Maret } 2020\end{array}$} & 08:00-09:00 & 34,28 \\
\hline & & 09:00-10:00 & 54,63 \\
\hline & & 10:00-11:00 & 55,05 \\
\hline \multirow{3}{*}{3} & \multirow{3}{*}{$\begin{array}{c}\text { Senin } 9 \\
\text { Maret } 2020\end{array}$} & 08:00-09:00 & 26,60 \\
\hline & & 09:00-10:00 & 33,43 \\
\hline & & 10:00-11:00 & 31,55 \\
\hline \multirow{3}{*}{4} & \multirow{3}{*}{$\begin{array}{c}\text { Selasa } 10 \\
\text { Maret } 2020\end{array}$} & 08:00-09:00 & 33,45 \\
\hline & & 09:00-10:00 & 50,82 \\
\hline & & 10:00-11:00 & 37,68 \\
\hline \multirow{3}{*}{5} & \multirow{3}{*}{$\begin{array}{c}\text { Rabu } 11 \\
\text { Maret } 2020\end{array}$} & 08:00-09:00 & 30,25 \\
\hline & & 09:00-10:00 & 34,37 \\
\hline & & 10:00-11:00 & 41,08 \\
\hline \multirow{3}{*}{6} & \multirow{3}{*}{$\begin{array}{l}\text { Kamis } 12 \\
\text { Maret } 2020\end{array}$} & 08:00-09:00 & 23,05 \\
\hline & & 09:00-10:00 & 27,70 \\
\hline & & 10:00-11:00 & 43,45 \\
\hline \multirow{3}{*}{7} & \multirow{3}{*}{$\begin{array}{c}\text { Jum'at } 13 \\
\text { Maret } 2020\end{array}$} & 08:00-09:00 & 36,58 \\
\hline & & 09:00-10:00 & 38,45 \\
\hline & & 10:00-11:00 & 30,58 \\
\hline \multirow{3}{*}{8} & \multirow{3}{*}{$\begin{array}{c}\text { Senin } 16 \\
\text { Maret } 2020\end{array}$} & 08:00-09:00 & 29,33 \\
\hline & & 09:00-10:00 & 33,22 \\
\hline & & 10:00-11:00 & 57,62 \\
\hline \multirow{3}{*}{9} & \multirow{3}{*}{$\begin{array}{l}\text { Selasa } 17 \\
\text { Maret } 2020\end{array}$} & 08:00-09:00 & 23,50 \\
\hline & & 09:00-10:00 & 21,37 \\
\hline & & 10:00-11:00 & 27,83 \\
\hline \multirow{3}{*}{10} & \multirow{3}{*}{$\begin{array}{c}\text { Rabu } 18 \\
\text { Maret } 2020\end{array}$} & 08:00-09:00 & 28,02 \\
\hline & & 09:00-10:00 & 26,65 \\
\hline & & 10:00-11:00 & 41,88 \\
\hline \multicolumn{3}{|c|}{ Total } & 1060,43 \\
\hline
\end{tabular}

$\mu=\frac{\text { jumlah total pasien yang dilayani }}{\text { jumlah total waktu lama pelayanan (dalam satuan jam) }}$

$\mu=\frac{1010}{17,7072}=57$ orang/jam

Berdasarkan data lama waktu pelayanan pasien dapat diketahui tingkat pelayanan $(\mu)$ yang dimiliki adalah 57 orang atau 1,05 menit/orang. 


\subsection{Pengolahan Data}

\subsubsection{Simulasi Antrian}

1. Uji Distribusi Probabilitas Data Kedatangan Pasien

Data yang akan diuji adalah data tabel 1 , data tersebut diuji distribusi probabilitas menggunakan ProModel. Berikut adalah hasil ujinya.

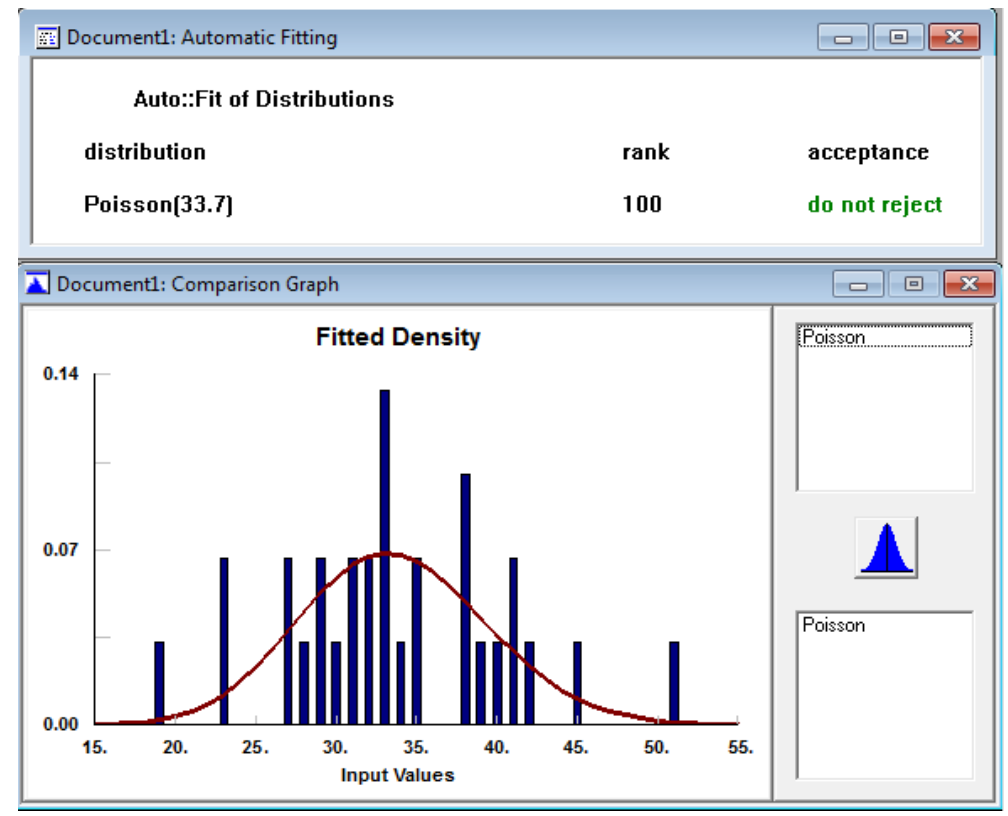

Gambar 2. Distribusi Kedatangan Pasien

Berdasarkan gambar 2 diketahui hasil uji data kedatangan pasien berdistribusi poisson.

2. Uji Distribusi Probabilitas Data Waktu Lama Pelayanan Pasien

Data yang akan diuji adalah data tabel 2, data tersebut diuji distribusi probabilitas menggunakan ProModel. Berikut adalah hasil ujinya.

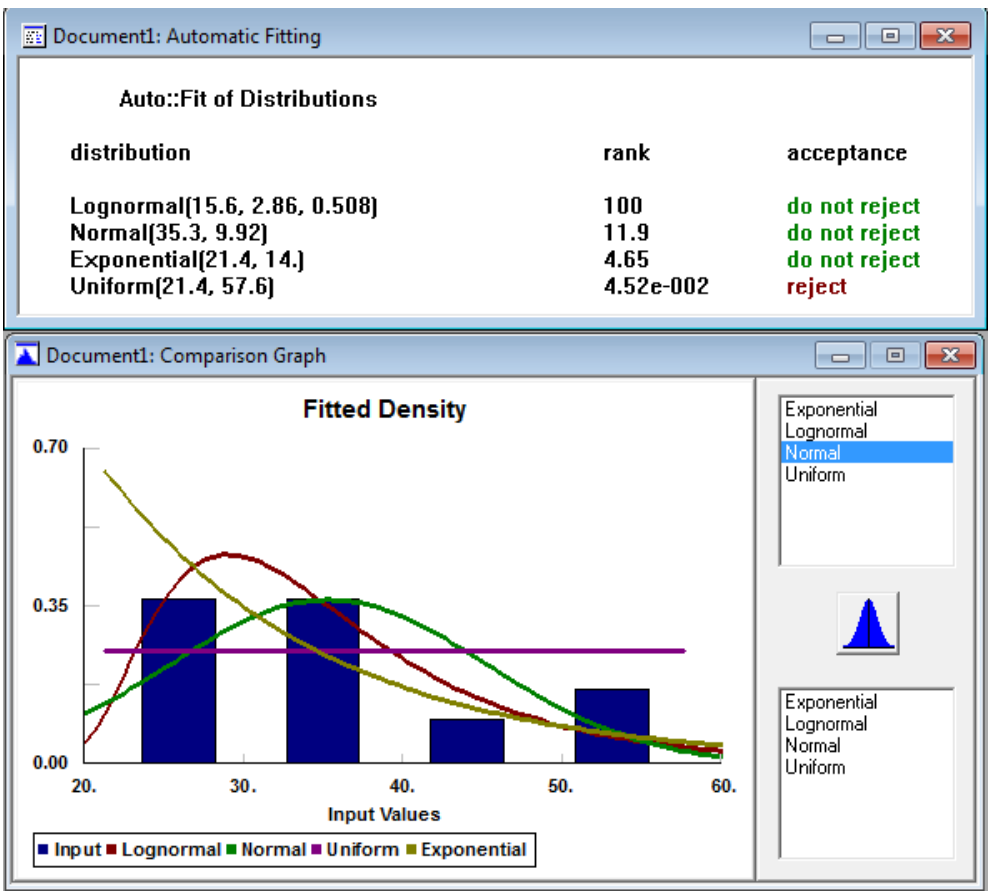

Gambar 3. Distribusi Lama Pelayanan Pasien 
PENINGKATAN SERVICE LEVEL (Mukhammad A. I., dkk.)

Berdasarkan gambar 3 diketahui hasil uji dengan ProModel data lama pelayanan pelanggan memiliki kecocokan dengan distribusi lognormal, normal, dan eksponensial. Berdasarkan hasil simulasi tersebut maka dipilih distribusi eksponensial untuk data lama pelayanan pasien.

3. Simulasi Antrian Pengambilan Obat

Simulasi ini menggunakan data waktu antar kedatangan dan data lama pelayanan lalu diolah menggunakan software ProModel sehingga diperoleh data-data yang dibutuhkan untuk membandingkan dengan kondisi nyata. Dari data keseluruhan didapat rata-rata waktu antar kedatangan pasien adalah 1,67 menit dan rata-rata waktu pelayanan adalah 1,05 menit. Proses yang terjadi pada saat simulasi ada beberapa proses yaitu:

1. Proses kedatangan pasien

2. Proses sebelum masuk ke server pengambilan obat

3. Proses pengambilan obat

4. Proses meninggalkan server

Pada gambar 4 sampai 8 ditampilkan modul input sesuai urutan proses untuk melakukan simulasi dengan ProModel.

\begin{tabular}{|c|c|c|c|c|c|c|}
\hline Icon & Name & Cap. & Units & $\mathrm{DTs} \ldots$ & Stats & Rules... \\
\hline & penyerahan_resep & inf & 1 & None & Time Series & Oldest, FIFO \\
\hline & pengambilan_obat & 1 & 1 & None & Time Series & Oldest, FIFO \\
\hline & ruang_tunggu & inf & 1 & None & Time Series & Oldest, FIFO \\
\hline & pintu_keluar & inf & 1 & None & Time Series & Oldest, FIFO \\
\hline
\end{tabular}

Gambar 4. Modul Locations.

\begin{tabular}{|l|l|l|l|} 
Icon & Name & Speed (mpm) & \\
\hline pasien & 150 & Time Series \\
\hline
\end{tabular}

Gambar 5. Modul Entities

\begin{tabular}{|l|l|l|l|l|l|}
\hline \multicolumn{1}{|c|}{ Entity... } & Location... & Qty Bach... & First Time.... & Occurrences \\
\hline pasien & penyerahan_resep & 1 & & \\
\hline
\end{tabular}

Gambar 6. Modul Arrivals

\begin{tabular}{|l|l|l|}
\hline \multicolumn{1}{|c|}{ Entity... } & \multicolumn{1}{|c|}{ Location... } \\
\hline pasien & penyerahan_resep & \\
\hline pasien & ruang_tunggu \\
pasien & pengambilan_obat \\
pasien & pintu_keluar
\end{tabular}

Gambar 7. Modul Process 
JOURNAL OF INTEGRATED SYSTEM VOL 4. NO. 1, JUNI 2021: 41-56

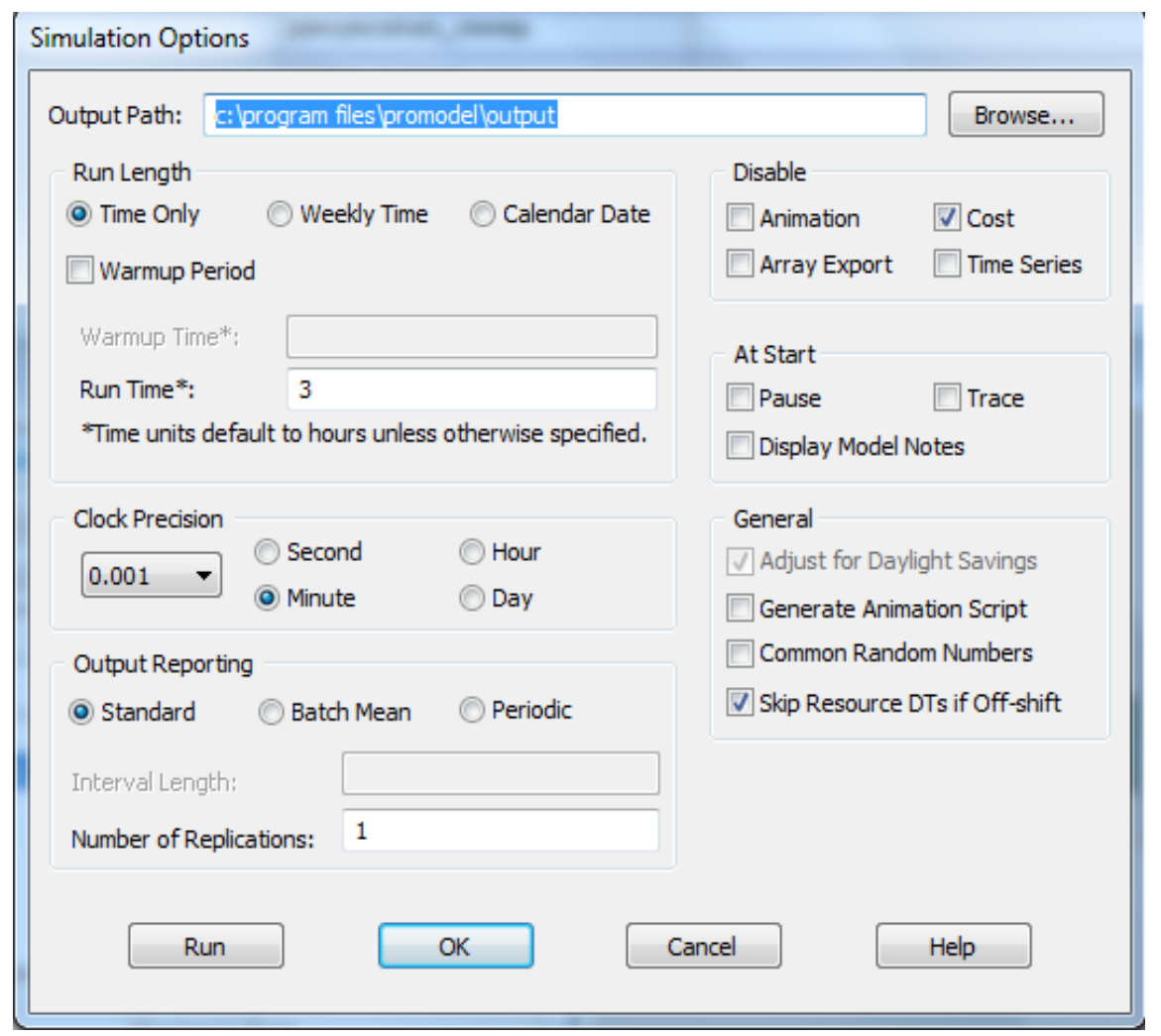

Gambar 8. Simulation Options

Simulasi antrian dilakukan dengan menggunakan satu sampai lima server, jumlah satu server merupakan kondisi awal sistem antrian, sedangkan dua sampai lima server merupakan kondisi usulan. Pada tabel 3 akan ditampilkan hasil dari simulasi sebagai berikut.

Tabel 3. Output Simulasi Antrian Promodel

\begin{tabular}{|c|c|c|c|c|c|c|}
\hline Jumlah Server & Satuan & 1 (Existing) & 2 (Usulan) & 3 (Usulan) & 4 (Usulan) & 5 (Usulan) \\
\hline Tingkat utilitas $(\rho)$ & $\%$ & 67,08 & 59,11 & 39,40 & 29,55 & 23,64 \\
\hline $\begin{array}{c}\text { Tingkat menganggur } \\
\left(\mathrm{P}_{0}\right)\end{array}$ & $\%$ & 32,92 & 40,89 & 60,60 & 70,45 & 76,36 \\
\hline $\begin{array}{c}\text { Jumlah pasien dalam } \\
\text { sistem (Ls) }\end{array}$ & Pasien & 1 & 1 & 1 & 1 & 1 \\
\hline $\begin{array}{c}\text { Jumlah pasien dalam } \\
\text { antrian (Lq) }\end{array}$ & Pasien & 0,7 & 0,59 & 0,39 & 0,3 & 0,24 \\
\hline $\begin{array}{c}\text { Waktu rata-rata } \\
\text { dalam sistem (Ws) }\end{array}$ & Menit & 5,27 & 2,72 & 2,72 & 2,72 & 2,72 \\
\hline $\begin{array}{c}\text { Waktu rata-rata } \\
\text { dalam antrian (Wq) }\end{array}$ & Menit & 1,13 & 0 & 0 & 0 & 0 \\
\hline Jumlah Server & Satuan & 1 (Existing) & 2 (Usulan) & 3 (Usulan) & 4 (Usulan) & 5 (Usulan) \\
\hline $\begin{array}{c}\text { Server dengan } \\
\text { Utilitas 0\% }\end{array}$ & Unit & 0 & 0 & 1 & 2 & 3 \\
\hline
\end{tabular}

Berdasarkan tabel 3 dapat diketahui bahwa penambahan server lebih dari satu akan menimbulkan server yang tidak terpakai atau server dengan untilitas $0 \%$. Hal ini dapat berpengaruh terhadap menurunnya tingkat utilitas server karena munculnya beberapa server yang tidak terpakai. 


\subsubsection{WISN}

1. Penetapan Waktu Kerja

Dihitung dengan rumus (1)

$\mathrm{A}=6$ hari kerja $\times 50$ minggu $=300$ hari kerja

$\mathrm{B}=12$ hari kerja (Undang-Undang No.13 tahun 2003 Pasal 79 ayat (2)).

$\mathrm{C}=6$ hari/tahun

$\mathrm{D}=16$ hari/tahun

$\mathrm{E}=5$ hari/tahun.

$\mathrm{F}=7 \mathrm{jam} / \mathrm{hari}$ (Allowance $1 \mathrm{jam})$.

$=7-1=6 \mathrm{jam} / \mathrm{hari}$

Waktu Kerja Tersedia $=(300-(12+6+16+5)) \times 6$

$$
=1.566 \mathrm{jam}=93.960 \text { menit }
$$

2. Menetapkan Unit Kerja dan Kategori SDM

Berdasarkan pengamatan, ditentukan 4 kategori aktivitas, yaitu aktivitas pelayanan langsung, aktivitas pelayanan tak langsung, aktivitas pribadi, dan aktivitas non produktif.

Tabel 4. Kategori Aktivitas Pelayanan

\begin{tabular}{|c|c|c|c|}
\hline No & Aktivitas & $\mathrm{F}$ (kali) & $\%$ \\
\hline \multirow[t]{5}{*}{1} & Aktivitas pelayanan langsung & & \\
\hline & $\begin{array}{l}\text { Menerima, memeriksa, memberi nomor } \\
\text { resep }\end{array}$ & 68 & 28,81 \\
\hline & Membuat etiket resep & 32 & 13,56 \\
\hline & Meracik obat & 23 & 9,75 \\
\hline & $\begin{array}{l}\text { Memeriksa kesamaan obat dengan resep, } \\
\text { menyerahkan obat dan penjelasannya }\end{array}$ & 35 & 14,83 \\
\hline \multirow[t]{7}{*}{2} & Aktivitas pelayanan tidak langsung & & \\
\hline & Pengumpulan dan pemilhan resep & 8 & 3,39 \\
\hline & Memeriksa obat untuk pelayanan & 7 & 2,97 \\
\hline & Rakapitulasi status ketersediaan obat & 6 & 2,54 \\
\hline & $\begin{array}{l}\text { Mencatat dan merekap pemakaian obat } \\
\text { psikotropika }\end{array}$ & 5 & 2,12 \\
\hline & Pencatatan resep & 23 & 9,75 \\
\hline & Memeriksa dan menata alat racikan & 8 & 3,39 \\
\hline \multirow[t]{5}{*}{3} & Aktivitas Pribadi & & \\
\hline & Izin & 4 & 1,69 \\
\hline & Sholat & 1 & 0,85 \\
\hline & Kamar mandi & 3 & 1,27 \\
\hline & Makan & 4 & 1,69 \\
\hline \multirow[t]{4}{*}{4} & Tidak Produktif & & \\
\hline & Mengobrol & 5 & 2,12 \\
\hline & Bermain smartphone & 3 & 1,27 \\
\hline & Total & 236 & 100 \\
\hline
\end{tabular}


3. Menghitung Standar Beban Kerja (SBK)

SBK dihitung dengan rumus (2).

Standar Beban Kerja untuk kegiatan Menerima, memeriksa, memberi nomor resep $=\frac{93.960 \text { menit }}{5 \text { menit }}=18.792$ menit

Tabel 5. SBK Tenaga Kerja

\begin{tabular}{|c|c|c|c|}
\hline $\begin{array}{c}\mathrm{N} \\
\mathrm{O}\end{array}$ & Aktivitas & Rata-rata waktu & SBK (menit) \\
\hline \multirow{5}{*}{1} & $\begin{array}{l}\text { Aktivitas pelayanan } \\
\text { langsung }\end{array}$ & & \\
\hline & $\begin{array}{l}\text { Menerima, } \\
\text { memerikds, memberi } \\
\text { nomor resep }\end{array}$ & 5 & 18.792 \\
\hline & Membust etiket resep & 3 & 31.320 \\
\hline & Meracik obat & 5 & 18.792 \\
\hline & $\begin{array}{l}\text { Memeriksa kesamaan } \\
\text { obat dengan resep, } \\
\text { menyerhkanobat dan } \\
\text { penjelasannya }\end{array}$ & 2 & 46.980 \\
\hline \multirow{7}{*}{2} & $\begin{array}{l}\text { Aktivitas pelayanan } \\
\text { tidak langsung }\end{array}$ & & \\
\hline & $\begin{array}{l}\text { Pengumpulan dan } \\
\text { pemilhan resep }\end{array}$ & 5 & 18.792 \\
\hline & $\begin{array}{l}\text { Memeriksa obat } \\
\text { untuk pelayanan }\end{array}$ & 7 & 13.423 \\
\hline & $\begin{array}{l}\text { Rekapitulasi status } \\
\text { ketersediaan obat }\end{array}$ & 9 & 10.440 \\
\hline & $\begin{array}{l}\text { Mencatat dan } \\
\text { merekap pemakaian } \\
\text { obat psikotropika }\end{array}$ & 6 & 15.660 \\
\hline & Pencatatan resep & 11 & 8.542 \\
\hline & $\begin{array}{l}\text { Memeriksa dan } \\
\text { menata alat racikan }\end{array}$ & 6 & 15.660 \\
\hline \multirow{5}{*}{3} & Aktivitas Pribadi & & \\
\hline & Izin & 15 & 6.264 \\
\hline & Sholat & 10 & 9.396 \\
\hline & Kamar mandi & 8 & 11.745 \\
\hline & Makan & 12 & 7.830 \\
\hline \multirow[t]{3}{*}{4} & Tidak Produktif & & \\
\hline & Mengobrol & 5 & 18.792 \\
\hline & Bermain smartphone & 2 & 46.980 \\
\hline
\end{tabular}

Berdasarkan tabel 5 diketahui aktivitas kerja terbesar ada dibagian aktivitas memeriksa kesamaan obat dengan resep, menyerahkan obat dan penjelasannya sebesar 46.980 menit, yang berarti tenaga kerja diharapkan dapat mengerjakan sejumlah 46.980 aktivitas memeriksa kesamaan obat dengan resep, menyerahkan obat dan penjelasannya dalam satu tahun, begitu juga dengan aktivitas lainnya. 
4. Menghitung Standar Kelonggaran

Standar kelonggaran bertujuan untuk memperoleh faktor kelonggaran SDM untuk kegiatan pribadi. Kelonggaran ini dikelompokkan berdasarkan kategori aktivitas yang dilakukan oleh seluruh karyawan dengan rumus 3 .

Tabel 6. Perhitungan Standar Kelonggaran

\begin{tabular}{|c|l|c|c|c|c|}
\hline No & \multicolumn{1}{|c|}{ Kegiatan } & Lama (Menit) & Frekuensi & Jumlah & Jumlah/WKT \\
\hline 1 & Izin & 15 & 24 & 3.600 & 0,0038 \\
\hline 2 & Sholat & 10 & 300 & 3.000 & 0,0319 \\
\hline 3 & Kamar mandi & 8 & 300 & 2.400 & 0,0255 \\
\hline 4 & Makan & 12 & 300 & 3.600 & 0,0383 \\
\hline & \multicolumn{4}{|c|}{ Total } & 0,0996 \\
\hline
\end{tabular}

Berdasarkan perhitungan, standar kelonggaran untuk kebutuhan pribadi sebesar 9,96\%, dimana setiap tenaga kerja mempunyai kelonggaran yaitu $9,96 \%$ per tahun untuk melakukan kegiatan pribadi.

5. Perhitungan Tenaga Kerja

Menurut apoteker Puskesmas Bojong Rawalumbu, didapatkan rata-rata resep masuk per hari adalah 95 resep per hari. Jumlah tersebut kemudian dikalikan dengan jumlah hari kerja sebanyak 26 hari kerja per bulan dan dikalikan dengan jumlah bulan sebanyak 12 bulan, sehingga didapatkan 29.640 resep/tahun. Dihitung dengan rumus (4).

Tabel 7. Kebutuhan Tenaga Kerja

\begin{tabular}{|c|l|c|c|c|}
\hline No & \multicolumn{1}{|c|}{ Aktivitas Pokok } & Kuantitas & $\begin{array}{c}\text { SBK } \\
\text { (menit) }\end{array}$ & $\begin{array}{c}\text { Kebutuhan } \\
\text { (orang) }\end{array}$ \\
\hline 1 & $\begin{array}{l}\text { Menerima, mengecek, memberi } \\
\text { nomor resep }\end{array}$ & 29.640 & 18.792 & 1,68 \\
\hline 2 & Memberi etiket resep & 29.640 & 31.320 & 1,05 \\
\hline 3 & Meracik obat & 29.640 & 18.792 & 1,68 \\
\hline 4 & $\begin{array}{l}\text { Memeriksa kesamaan obat dengan } \\
\text { resep, menyerahkan obat dan } \\
\text { penjelasannya }\end{array}$ & 29.640 & 46.980 & 0,73 \\
\hline 5 & Pengumpulan dan pemilihan resep & 254 & 18.792 & 0,11 \\
\hline 6 & Memeriksa obat untuk pelayanan & 254 & 13.423 & 0,12 \\
\hline 7 & Rekapitulasi status ketersediaan obat & 12 & 10.440 & 0,10 \\
\hline 8 & $\begin{array}{l}\text { Mencatat dan merekap pemakaian } \\
\text { obat psikotropika }\end{array}$ & 2.470 & 15.660 & 0,26 \\
\hline 9 & Pencatatan resep & 29.640 & 8.542 & 3,57 \\
\hline 10 & $\begin{array}{l}\text { Membersihkan dan merapikan alat } \\
\text { racikan }\end{array}$ & 900 & 15.660 & 0,16 \\
\hline & \multicolumn{2}{|r|}{ Total } & 9,45 \\
\hline
\end{tabular}

Berdasarkan tabel 7 diketahui tenaga kerja yang dibutuhkan apotek Puskesmas sebanyak 9,45 atau 10 orang. Tenaga kerja dengan kebutuhan terbesar ada di bagian pencatatan resep yaitu 3,57 (4 orang) diikuti bagian meracik obat dan bagian menerima, memeriksa, memberi nomor resep yaitu 1,68 (2 orang). Adapun pekerjaan utama staff loket yang memiliki dampak langsung dengan waktu pelayanan adalah aktivitas pertama dan ke-empat, dengan jumlah tenaga kerja yang memiliki efek langsung sebanyak 2,41 orang atau dua sampai tiga. Pada 
sistem nyata, apotek Puskesmas telah memiliki satu orang pekerja pada bagian loket pengambilan obat.

\section{Kesimpulan}

Berdasarkan hasil pengolahan data, analisis dan pembahasan, maka dapat ditarik kesimpulan sebagai berikut:

1. Kondisi model yang tersedia saat ini adalah 1 server dengan model antrian yaitu $(\mathrm{M} / \mathrm{M} / 1) ;(\mathrm{FIFO} / \infty / \infty)$ yang artinya pelayanan saat ini menggunakan 1 server dengan disiplin antrian Fisrt In First Out dan populasi kedatangan yang tak terbatas serta tidak dapat diprediksi.

2. Penggunaan 3 server atau lebih akan memunculkan server yang memiliki tingkat utilitas $0 \%$ yang berarti server tersebut tidak memiliki fungsi atau tidak diperlukan.

3. Jumlah server yang terbaik adalah 2 server dengan model antrian yang sesuai yaitu $(\mathrm{M} / \mathrm{M} / 2) ;(\mathrm{FIFO} / \infty / \infty)$. Hal ini didukung dengan analisis WISN yang menyatakan bahwa jumlah ideal untuk bagian loket pengambilan obat adalah 2 - 3 orang.

\section{Daftar Pustaka}

Amalia, R., Saumi, F., Novianti, D., \& Ulfa, C. (2018), Pemodelan Sistem Antrian Poli Jantung di RSUD Kota Langsa Menggunakan Struktur Antrian Single Channel-Single Phase. Paper presented at the Seminar Nasional Pendidikan Matematika Ahmad Dahlan.

Camerling, B., \& Manusiwa, J. P. (2017), Model Simulasi Untuk Menganalisis Kinerja Sistem Antrian Kapal Tanker Pada Dermaga PT. Pertamina Tbbm Wayame Ambon, Arika, 11(1), 21-34.

Cornellia, R. (2018), Analisis Antrian pada Loket Pembuatan Elektronik KTP dengan Menggunakan Simulasi Promodel, Jurnal String, 3(2), 119-129

Dimyati, T. T., \& Dimyati, A. (2011), Operations Research Model-model Pengambilan Keputusan, Bandung: Sinar Baru.

Falen, F. F., \& Subagyo, S. (2018), Simulasi Antrian Pasien Rawat Inap untuk Mengurangi Waiting List VIP di Rumah Sakit, Jurnal Teknosains, 8(1), 13-25.

Heizer, J., \& Render, B. (2015), Operations Management (Manajemen Operasi), ed. 11, Penerjemah: Dwi Anoegrah Wati S. dan Indra Almahdy, Salemba empat, Jakarta.

Suryo Agung Nugroho (2013), Strategi Pemasaran Sekolah Berbasis Bauran Pemasaran SMKN 1 Ngawen Gunung Kidul, Nucleic Acids Research, 34(11), e77-e77.

Jatmika, S., Prasetyo, T., \& Poernomo, B. (2017), Analisis Antrian Model Multi Channel-Singel Phase Dan Optimalisasi Layanan Akademik (Studi Kasus Pada STMIK ASIA Malang), Positif, 3(1), 41-46.

Kelton, W. D., Sadowski, R. P., \& Zupick, N. (2015), Simulation with Arena, McGraw-Hill.

Keputusan Menteri Kesehatan Republik Indonesia Nomor: 81/MENKES/SK/I/2004 tentang Pedoman Penyusunan Perencanaan Sumber Daya Manusia Kesehatan di Tingkat Propinsi, Kabupaten/Kota, 2004.

Krajewski, L. J., Ritzman, L. P., \& Malhotra, M. K. (2010), Operations Management: Processes and Supply Chains, Pearson Upper Saddle River, New Jersey.

Kusumaningtyas, T., Fikri, M. I., \& Liquiddanu, E. (2018), Simulasi Antrian Pengisian Bahan Bakar Di SPBU Pucangsawit. Paper presented at Seminar dan Konferensi Nasional IDEC, Surakarta. 
Mahessya, R. A., Putra, R. D., \& Veri, J. (2019), Pemodelan dan Simulasi Penerapan Antrian Multiphase pada Antrian Pembuatan SIM Pengendara Sepeda Motor Dipolres Sijunjung, Jurnal Sains dan Informatika: Research of Science and Informatic, 5(1), 31-38.

Mukarrama, F., \& Fadjryani, F. (2017), Sistem Antrian Single Channel-Multiple Phase Dalam Meningkatkan Pelayanan Pembayaran Pajak Kendaraan Bermotor di Kantor Sistem Administrasi Manunggal Satu Atap (Samsat) Kota Palu, Natural Science: Journal of Science and Technology, 6(2). 175-186

Mulyati, D., Qasir, A., Alsyah, O., Yana, S., \& Satria, D. (2019), Model Antrian Pada Apotek Puskesmas Ingin Jaya Aceh Besar. Paper presented at the Seminar Nasional Teknik Industri.

Muninggar, P. R., Linawati, L., \& Parhusip, H. A. (2019), Analisis Sistem Antrian dengan Simulasi di Puskesmas Cebongan Kota Salatiga, Jurnal Fourier, 8(2), 57-64.

Nasution, A. S., \& Mutia, S. (2017), Analisis Sistem Antrian pada Loket Pendaftaran Pasien di Puskesmmas Padang Pasir Kecamatan Padang Barat, Jurnal Sains dan Teknologi: Jurnal Keilmuan dan Aplikasi Teknologi Industri, 17(2), 120-125.

Organization, W. H. (2010), Workload indicators of staffing needs (WISN), User's Manual: Geneva.

Shipp, P. J. \& Organization, W. H. (1998), Workload Indicators of Staffing Need (WISN): A Manual For Implementation, World Health Organization.

Sujoko, A., \& Chalidyanto, D. (2015), Analisis Antrian Pelayanan Obat Non Racikan di Instalasi Farmasi Rawat Jalan, Jurnal Administrasi Kesehatan Indonesia, 3(2), 99-107.

Trenggonowati, D. L. (2017), Optimasi Proses Produksi dengan Menggunakan Pendekatan Simulasi Sistem, Penelitian dan Aplikasi Sistem dan Teknik Industri, 11(1), 1-12.

Utami, O. W., \& Rumita, R. (2016), Analisa Beban Kerja Pegawai dan Usulan Perbaikan Sistem Antrian pada Instalasi Farmasi Depo Askes RSUD Dr Soeselo Slawi, Industrial Engineering Online Journal, 5(4).

Winarno (2014), Perancangan Simulasi Kejadian Diskret Dalam Menentukan Interval Keberangkatan Angkutan Kota Untuk Memaksimalkan Pendapatan Pengemudi Angkutan. Paper presented at the Seminar Nasional Teknik Industri Badan Kerjasama Penyelenggara Pendidikan Tinggi Teknik Industri, Bukit Tinggi. 